\title{
Interactions of caligid ectoparasites and juvenile gadids on Georges Bank
}

\author{
John D. Neilson, R. Ian Perry, J. S. Scott, P. Valerio* \\ Marine Fish Division, Department of Fisheries and Oceans, Biological Station, St. Andrews, New Brunswick E0G 2X0, Canada
}

\begin{abstract}
The role of the ectoparasite Caligus sp. (Copepoda: Caligidae) in the northeast Georges Bank cod-haddock ecosystem was examined. Vertical distribution of free-living Caligus elongatus adults and host-parasite relationships of juvenile Caligus sp. and juvenile gadids are described at 2 locations with contrasting oceanographic properties, one thermally stratified and the other well-mixed. Cod Gadus morhua had both greater prevalence and number of Caligus sp. ectoparasites than did haddock Melanogrammus aeglefinus at both locations. Preferred sites of attachment on the host also differed. While no direct evidence of reduced fish condition as a function of parasite infestation was found, circumstantial evidence is offered in support of the hypothesis that Caligus sp. ectoparasitism is a source of mortality for young haddock. Free-living $C$. elongatus were demonstrated to be a significant component of fishes diet, particularly for cod at the stratified site where zooplankton were less abundant.
\end{abstract}

\section{INTRODUCTION}

The northeast portion of Georges Bank (NW Atlantic) is important for the production of commercially significant gadids, particularly cod Gadus morhua and haddock Melanogrammus aeglefinus. Surveys of the pelagic stages of O-group gadids conducted by Canadian and United States fisheries agencies have consistently revealed that highest catch rates occur in that vicinity (Cohen et al. 1985, Koeller et al. 1986). In common with other investigations of stocks of gadids world-wide, the Georges Bank studies are often based on the premise that year-class strength is correlated with the extent of natural mortality during the first year of life.

Such work has generally considered predation to be the most important contributor to natural mortality in the first year of life (Sissenwine 1984), and until now parasitism has not received attention. This lack of knowledge is particularly significant given the emerging view that parasitism may have as important a role in the regulation of abundance of natural communities as predation and competition (Dobson \& Hudson 1986).

\footnotetext{
- Present address: Department of Biology, Memorial University of Newfoundland, St. John's, Newfoundland A1B 3X9, Canada
}

In this paper, we examine the role of the ectoparasite Caligus sp. (Copepoda: Caligidae) in the northeast Georges Bank cod-haddock ecosystem.

Caligid ectoparasites are known to be damaging to young fish (Rosenthal 1967. Wootten et al. 1982). For example, Kabata (1972) found that the feeding activity of Caligus clemensi attached to young pink salmon Oncorhynchus gorbuscha resulted in the loss of entire fins. Wootten et al. (1982) revealed that C. elongatus, when present on fish in large numbers, can be debilitating even for adult Atlantic salmon Salmo salar. Kabata (1974) described the feeding activity of caligid parasites in detail: the fish tissues are scraped off by the strigil (a masticatory apparatus) and the debris is then picked up by the mandibles and conveyed into the buccal cavity. Preliminary histological examination has indicated that the site of attachment and feeding may extend deeper into the fishes' bodies than previously thought (S. MacLean, Oxford, Laboratory, National Marine Fisheries Service, Maryland, USA, pers. comm.). As the ectoparasite can be of considerable size (later chalimus stages are about $10 \%$ of the length of the juvenile fish host), indirect effects on the natural mortality of fish might also be expected. Such effects might include increased drag, causing reduced ability to avoid predation, and increased visibility to predators (Holmes \& Bethel 1972). 
Despite the potentially damaging effects of caligid copepods, their ontogeny and effects on commercially important North Atlantic fish species remain largely unknown. What little ontogenetic information is available was summarized by Kabata (1981). In caligid copepods, 2 stages of nauplii and 5 stages of chalimi occur, followed by 2 pre-adult stages and finally the adult form. The infective stage is the first chalimus, with all chalimus stages parasitic. The nauplii are freeliving and the adults are either free-living or, more rarely, parasitic.

As part of a larger study of the vertical distribution of young pelagic gadids in differing oceanographic regimes, we studied the occurrence of free-living Caligus elongatus and parasitic forms of Caligus sp. (probably also C. elongatus) at 2 sites on Georges Bank, one thermally stratified and the other well-mixed. As freeliving forms were common members of the zooplankton community at both sites, we were able to describe feeding of gadids on Caligus sp. as well as the hostparasite interactions.

\section{METHODS}

The 2 sites for this study were located on the northeast peak of Georges Bank in the NW Atlantic (Fig. 1). They represented distinct water masses, which CTD profiles indicated were thermally well-mixed at the

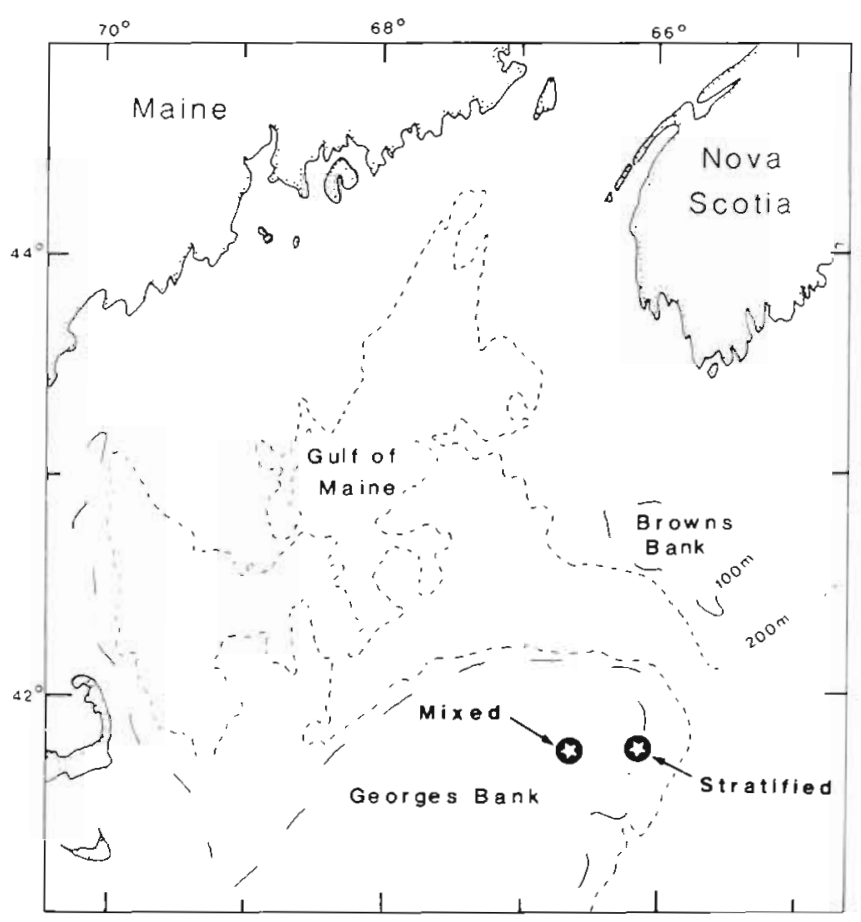

Fig. 1 Location of mixed and stratified sampling sites, Georges Bank, NW Atlantic, 1985 shallower site $(60 \mathrm{~m})$ and stratified at the deeper site $(80 \mathrm{~m})$ for the duration of the study. All sampling, which included pelagic trawling and oceanographic data collections, was repeated every 4 h both at the mixed site (48 h sampling period, 22 to 24 Jun 1985) and at the stratified site ( $24 \mathrm{~h}$ sampling period, 25 to $26 \mathrm{Jun}$ ).

Two vessels working in tandem were used for sampling. Fishing operations were conducted from the FRV Alfred Needler, using an International Young Gadoid Pelagic Trawl (IYGPT) towed at 3.5 knots for $0.5 \mathrm{~h}$ at depths of 50,30 and $15 \mathrm{~m}$ sequentially, with the catch being retrieved from each depth before setting to the next. The IYGPT has a nominal vertical opening of about $7 \mathrm{~m}$ and a headrope length of $28 \mathrm{~m}$, measured from wing to wing. Mesh size in the codend is $5 \mathrm{~mm}$ (stretched). All fish were identified, enumerated and a subsample of cod and haddock preserved in $4 \%$ Formalin for subsequent laboratory examination of parasites and gut contents.

CTD profiles and a series of horizontal tows using a multiple opening-closing zooplankton sampler (MININESS, mouth opening $0.25 \mathrm{~m}^{2}$ with net mesh size 333 $\mu \mathrm{m}$, tow speed $2.5 \mathrm{knots})$ were made from the RV Lady Hammond in each $4 \mathrm{~h}$ sampling block. The MININESS was used to sample 8 depth strata sequentially from near-bottom to near-surface. Tow duration was 10 min at each step. Four of the depth strata selected overlapped with the 3 depths fished by the IYGPT. All zooplankton collected were preserved in $4 \%$ Formalin.

Measurements onshore consisted of recording the standard lengths of preserved samples of juvenile cod and haddock (based on a comparison of fresh and preserved lengths of 20 individual cod and haddock, an average correction factor for shrinkage of cod and haddock was determined to be 1.16 and 1.18 respectively) and counting and measuring (total length) attached Caligus sp. Identification of the immature parasitic stages was possible to the genus level only, due to lack of knowledge on the systematics of early life-history stages of caligid copepods (pers. comm., Z. Kabata, Pacific Biological Station, Nanaimo, British Columbia, Canada). However, since adult C. elongatus was the only caligid collected during concurrent zooplankton tows, it is likely that the parasitic forms were also $C$. elongatus. Counts of the ectoparasites were made with the aid of a dissecting microscope. Losses of the ectoparasites due to handling and storage were less than $9 \%$, based on counts of chalimi found in the bottom of fish sample containers. Gut contents from the preserved fish were also examined and the occurrence of all life-history stages of Caligus sp. noted. Eggs of Caligus sp. were readily identifiable and not likely to be confused with other invertebrate eggs, due to their unique disk-like shape. 
To test the hypothesis that more extensively parasitized fish were captured by the smaller sampling gear (MININESS) and hence make inferences regarding parasitized fishes' swimming ability, we not only enumerated the parasites but also measured their total biomass (dry weight, obtained with a Cahn electrobalance) as a function of host length. In this fashion, we hoped to account for the occurrence of the various sizes of the attached chalimus stages of Caligus sp. as they underwent their series of moults. We also calculated Fulton's K (weight/length ${ }^{3}$ ), an index of fish condition, as a function of the number of attached Caligus sp. Fish which had obvious internal parasites, including nematodes and tapeworms, were excluded from the analysis.

Adult Caligus elongatus from the MININESS collections which corresponded to the depths fished by the IYGPT were identified and counted. Mean depths $\left(Z_{m}\right)$ of the vertical distribution during each time block were calculated as

$$
\mathrm{z}_{\mathrm{m}}=\frac{\sum \mathrm{n}_{\mathrm{i}} \mathrm{Z}_{1}}{\sum \mathrm{n}_{\mathrm{i}}}
$$

where $n_{1}=$ number of $C$. elongatus at depth $Z_{1}$ (Pearre 1973). To derive a crude measure of relative abundance of potential prey items for juvenile gadids at the 2 locations, displacement volumes of zooplankton were also obtained, exclusive of large gelatinous zooplankton. Comparisons of the abundance of free-living $C$. elongatus at the 2 sites and the numbers of attached parasites in fish of both species at the 2 sites were made using box and whisker plots (Tukey 1977), which are graphical representations of a variable's descriptive statistics. The left and right margins of the box represent the 25 and 75 th percentile, respectively, with the whiskers extending to values equal to 1.5 times the spread from the median (depicted as a bold vertical line) to the corresponding edge of the box. Values outside of such ranges are considered outliers and are plotted individually. A total of 1114 fish and 77 zooplankton samples were examined during the course of this study. Of the $1114 \mathrm{fish}, 413 \mathrm{cod}$ and 310 haddock were examined for gut contents, in particular for the occurrence of $C$. elongatus, and were also used to examine effects of host size, site and species on the extent of ectoparasitism. A further 211 fish were used in the study of fish condition as a function of extent of parasitism. Finally, the remaining 180 fish were used to examine the distribution of Caligussp. on the host's body.

\section{RESULTS}

Temperature profiles at noon of the first day of sampling at each site are shown in Fig. 2. The water column at the mixed site was isothermal $\left(10^{\circ} \mathrm{C}\right)$, with some indication of daytime heating in the upper $5 \mathrm{~m}$. At the stratified site, a distinct thermocline occurred between 10 and $30 \mathrm{~m}$. CTD profiles repeated every $4 \mathrm{~h}$ indicated that the base of the thermocline fluctuated between 18 and $30 \mathrm{~m}$ depth. However, the temperature difference from $>12{ }^{\circ} \mathrm{C}$ at the surface to $8^{\circ} \mathrm{C}$ at $30 \mathrm{~m}$ persisted. At both sites, salinity variations were relatively small and consistent with the temperature profiles.

Differences in abundance of free-living forms of Caligus elongatus at the 2 sites are shown in Fig. 3. Significantly more occurrences were noted at the mixed site than at the stratified site (Mann-Whitney U-test, p $<0.001)$. The occurrence of $C$. elongatus was also found to be positively correlated with depth at the stratified site (dependent variable square-root transformed, 2-way analysis of variance, $p<0.001$ ), although no correlation was found with time of day ( $p$ $=0.117)$. Neither time $(p=0.421)$ nor depth $(p=0.139)$ was correlated with $C$. elongatus abundance at the mixed site. However, the alternative approach of

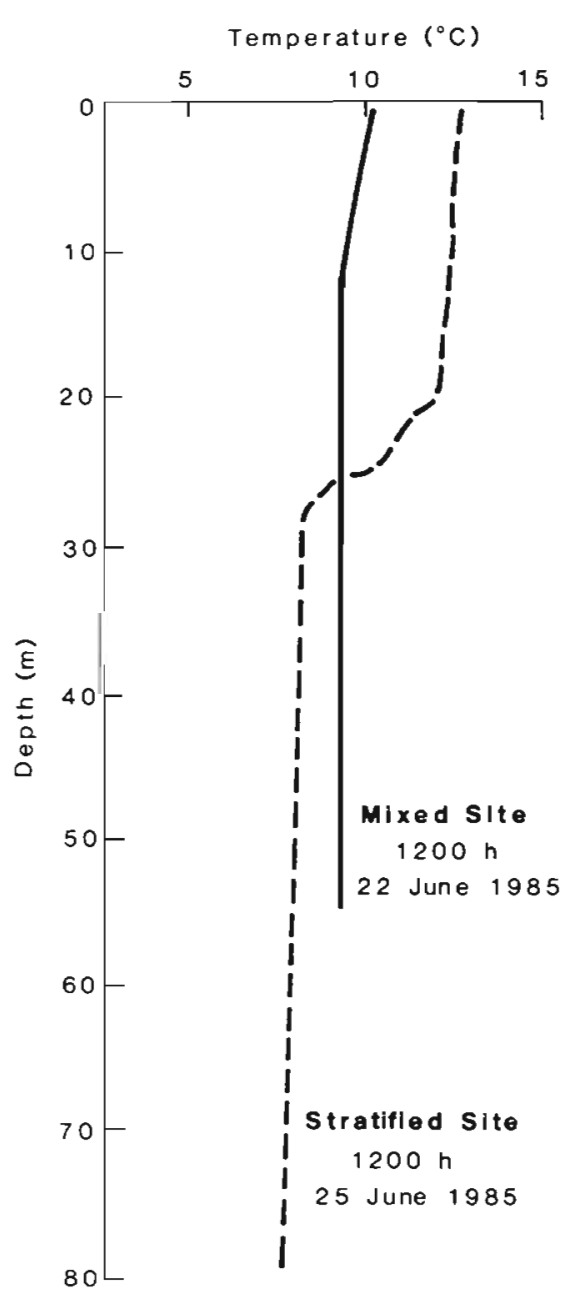

Fig. 2. Temperature profiles at the mixed and stratified sites, Georges Bank, 1985 
examining depth-stratified abundance data revealed changes in the vertical distribution of adult $C$. elongatus over time (Fig. 4), particularly at the mixed site. These distributions are summarized within each of the $4 \mathrm{~h}$ sampling periods by the mean depth, which indicated periodic changes in the depth distribution at the mixed site that were not clearly related to a diel cycle. Changes in the depth centre of mass were relatively small at the stratified site.

An example of a parasitized cod is shown in Fig. 5. The chalimus stage of Caligus sp. appeared to be most often attached to particular locations on the bodies of juvenile gadids (Fig. 6). Sites commonly parasitized in cod included the insertion of the fins, particularly the pelvic, and in haddock, the vicinity of the head (particularly around the preopercular, interopercular, sub-

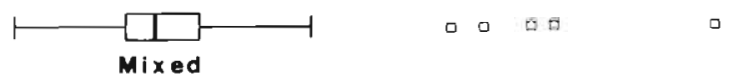

$\longrightarrow \mathrm{DP}$

Stratified

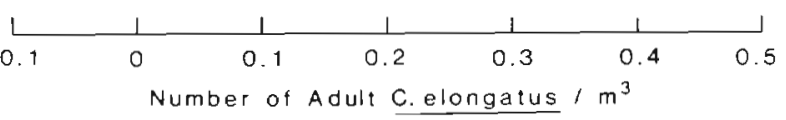

Fig. 3. Caligus elongatus. Box and whisker plots of the number of free-living adults caught in MININESS tows at the mixed and stratified sites, Georges Bank, 1985

orbital and around the ventral half of the opercular bones). Several length modes of Caligus sp. were appa-
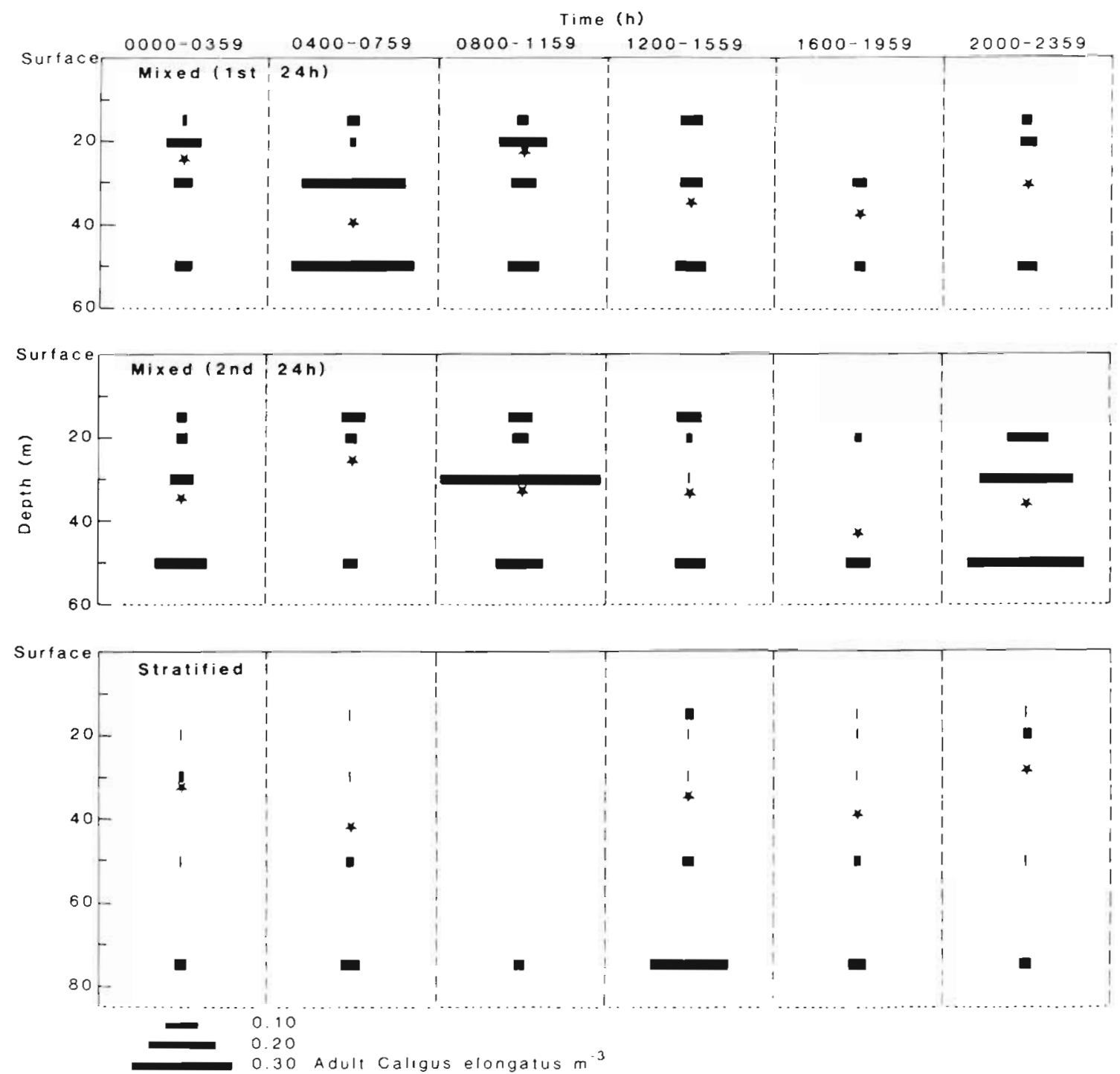

Fig. 4. Caligus elongatus. Distribution of catches of free-living adults in MININESS tows at the mixed and stratified sites, plotted with respect to time and depth. Georges Bank, 1985. Mean depths of the distribution $\left(Z_{m}\right)$ are plotted as stars within each time 
rent, and were found parasitizing all length classes of cod (Fig. 7). The number of attached parasites decreased with increasing fish length for both cod and haddock, although there was considerable variability in these relationships (Fig. 8). In general, cod were more heavily parasitized than were haddock, even when the comparison was standardized for fish length (2-way analysis of variance, dependent variable square-root transformed, $\mathrm{p}<0.001$ ).

The number of Caligus sp. on cod at the mixed site was greater than at the stratified site (Fig. 9, MannWhitney U-test, $p<0.001$ ). However, on haddock, the site-specific difference was significant at a lower level of probability (Fig, 9, Mann-Whitney U-test, $p=0.046$ )

We found that gadids were taking Caligus sp. as prey at the stratified site more often than at the mixed site, with Caligus sp. present as eggs or adults in 41 of 235 $(17.5 \%)$ cod stomachs examined from the stratified site compared with only 8 of $178(4.5 \%)$ cod stomachs from the mixed site. The numerical significance of Caligus $\mathrm{sp}$. relative to the other prey items taken by cod is shown in Table 1. All 11 cod stomachs containing eggs of Caligus sp. originated from the stratified site. Caligus sp. eggs were the numerically most abundant prey item at the stratified site. However, in 4 instances where Caligus sp. eggs were found, ovarian tissue was

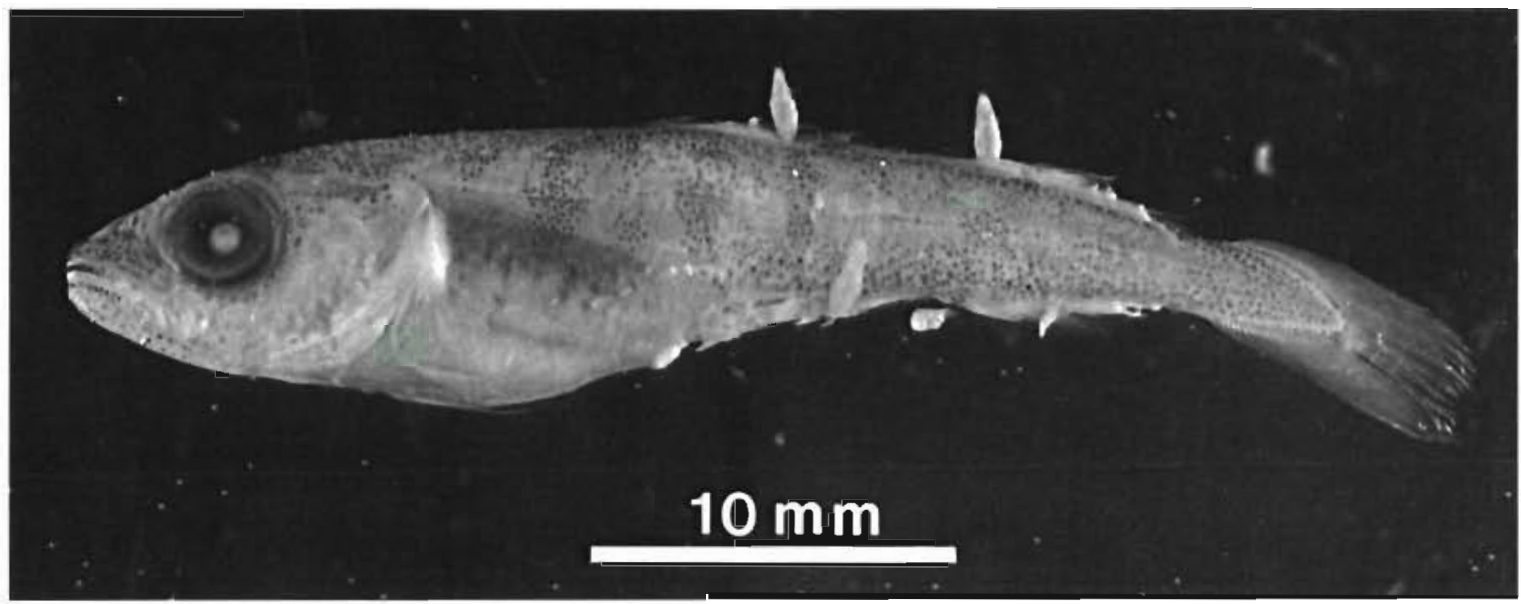

Fig. 5. Gadus morhua. An example of Atlantic cod moderately parasitized by Caligus sp. Georges Bank, 1985

Cod
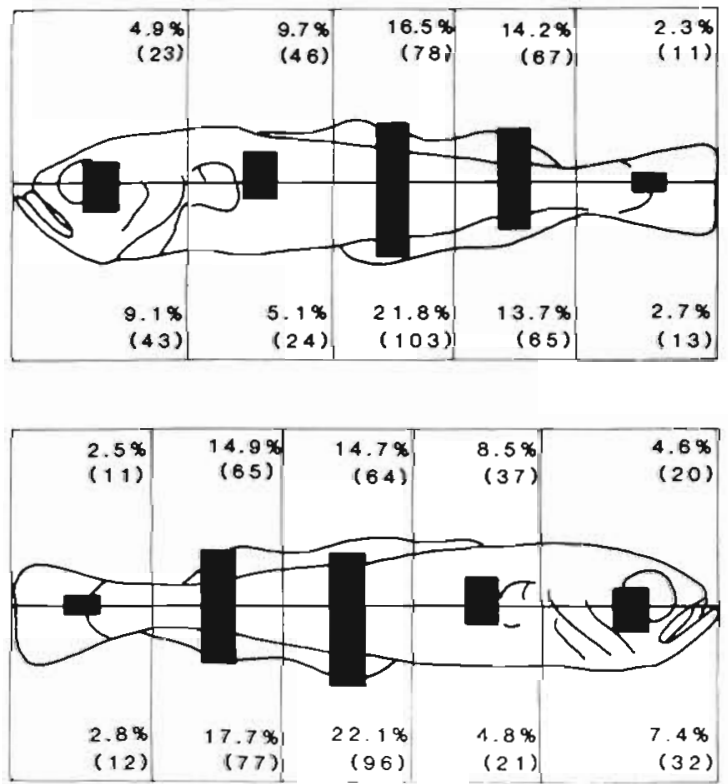

\section{Haddock}
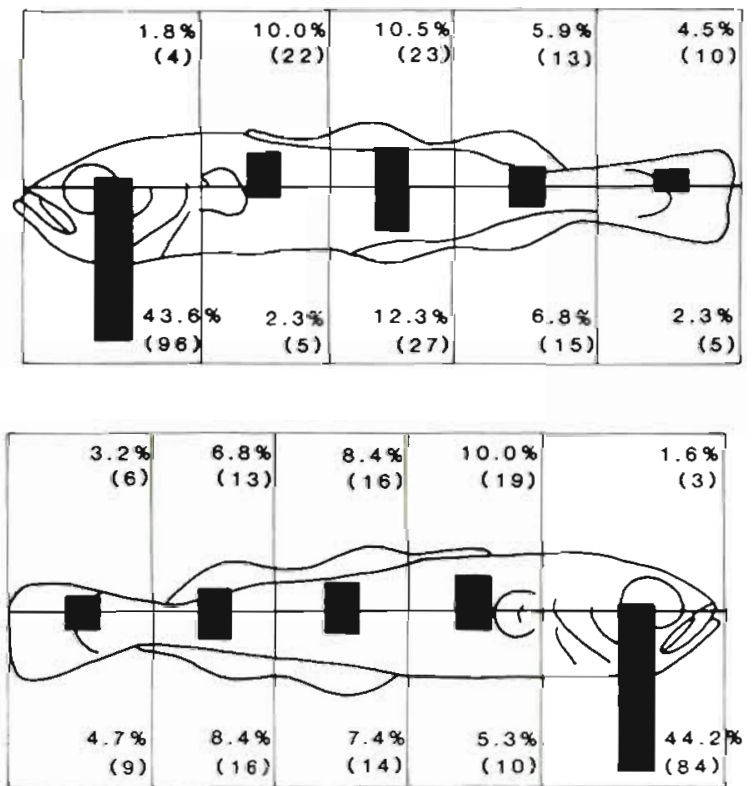

Fig. 6. Gadus morhua and Melanogrammus aeglefinus. Distribution of attachment sites of chalimus stages of Caligus sp. on age-0 Atlantic cod $(n=100)$ and haddock $(n=80)$. Georges Bank, 1985. Vertical bars indicate percentage of all parasites found within that sector of the fishes' bodies. Percentage value and number of parasites found in each portion of the body are also given 


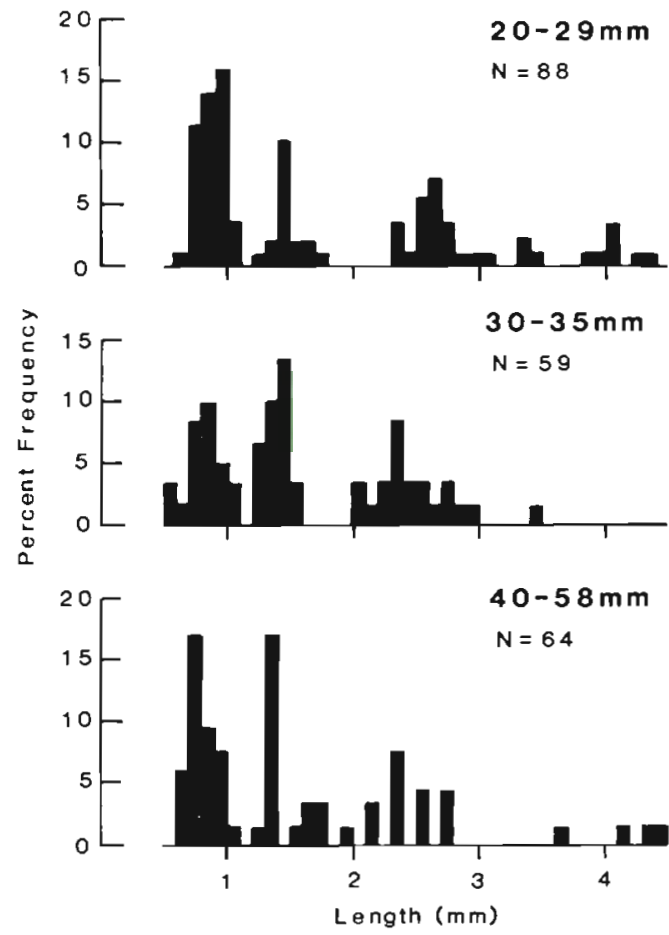

Fig. 7. Length-frequency distrubutions of the ectoparasite on various length classes of age-0 Atlantic cod Gadus morhua Georges Bank, 1985

attached and adult Caligus elongatus were also present in the stomach contents, indicating that the eggs may have originated from ingested gravid females rather than as separate pelagic prey items. Caligus sp. appeared to be a less significant component of the diet of haddock, as they were present in only 2 of 180 $(1.1 \%)$ and 4 of $130(3.1 \%)$ stomachs from the mixed and stratified sites, respectively. The numerical occurrence of Caligus $\mathrm{sp}$. relative to the other prey items taken by haddock is also shown in Table 1. Eggs of Caligus sp. were found in one haddock stomach only, originating from the stratified site.

Fulton's K (weight/length ${ }^{3}$ ) was used to examine whether the extent of parasitism was correlated with fish condition. For both cod and haddock, we could find no significant correlation of parasite burden with fish condition $(\mathrm{p}>0.05)$.

To determine whether parasitism by Caligus $\mathrm{sp}$. affected the gadids' swimming ability, we examined the parasite burden of fish caught in the relatively small MININESS compared with the much larger IYGPT net. Initial comparisons of the biomass and numbers of parasites indicated that a significantly higher parasite burden occurred in fish caught in the smaller gear (Mann-Whitney U-test, $p=0.040$ and 0.009 for weight and numbers respectively), indicating that vulnerability to capture may have increased with the parasite burden. However, when fish length was included as a covariate, the relation between gear type and extent of parasitism was no longer significant (2way analysis of variance, $p>0.05$, dependent term square-root transformed).

In our examination of gut contents, we found that 0 group haddock were feeding on other 0-group gadids (Table 1). If ingested gadids had greater numbers of attached Caligus sp., further support would be lent to the hypothesis that heavily parasitized fish had reduced swimming ability and hence reduced success in avoiding predation. However, our data indicated that the number of attached Caligus sp. on gadids ingested by haddock and on gadids collected in the IYGPT did not differ significantly (Mann-Whitney Utest, $p>0.05)$. Since we were not able to obtain biomass measurements of the attached Caligus sp. due to the often advanced stage of digestion, and furthermore the number of ingested gadids was small $(n=25)$, this conclusion should be treated with caution.

\section{DISCUSSION}

The effects of ectoparasitism on the fish host may be physiological or mechanical. Physiological effects include the drain of metabolic resources or reaction of the host, locally or generally, to the invasion of tissues or secretions from the parasite, resulting in a decreased activity level. Examples of mechanical effects include

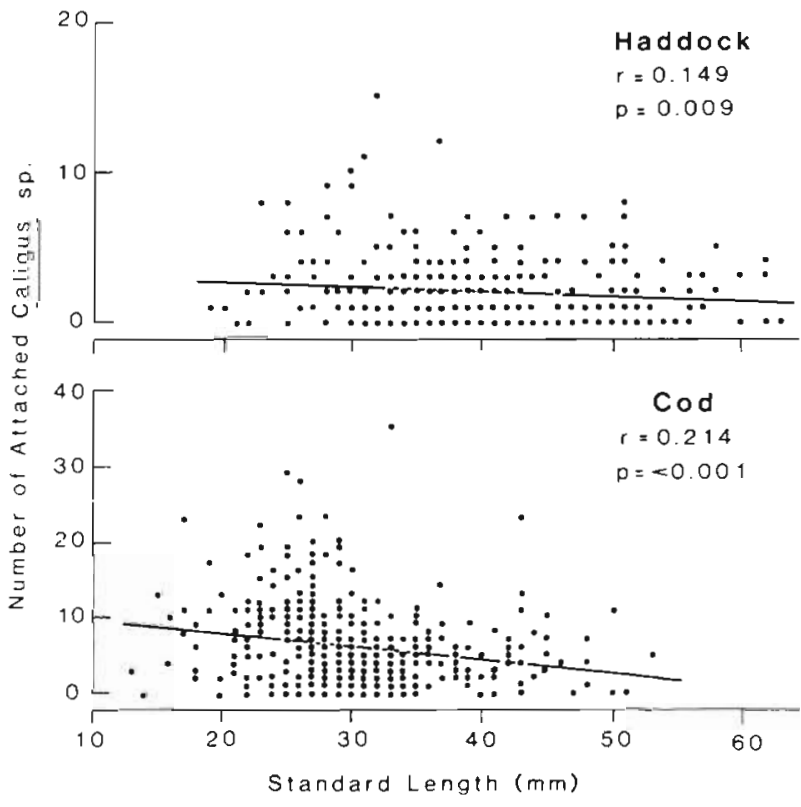

Fig. 8. Regressions of number of attached parasites Caligus sp. vs standard length of the host age-0 Allantic cod Gadus morhua or haddock Melanogrammus aeglefinus. Georges Bank, 1985. $N=413$ and 310 for cod and haddock, respectively 


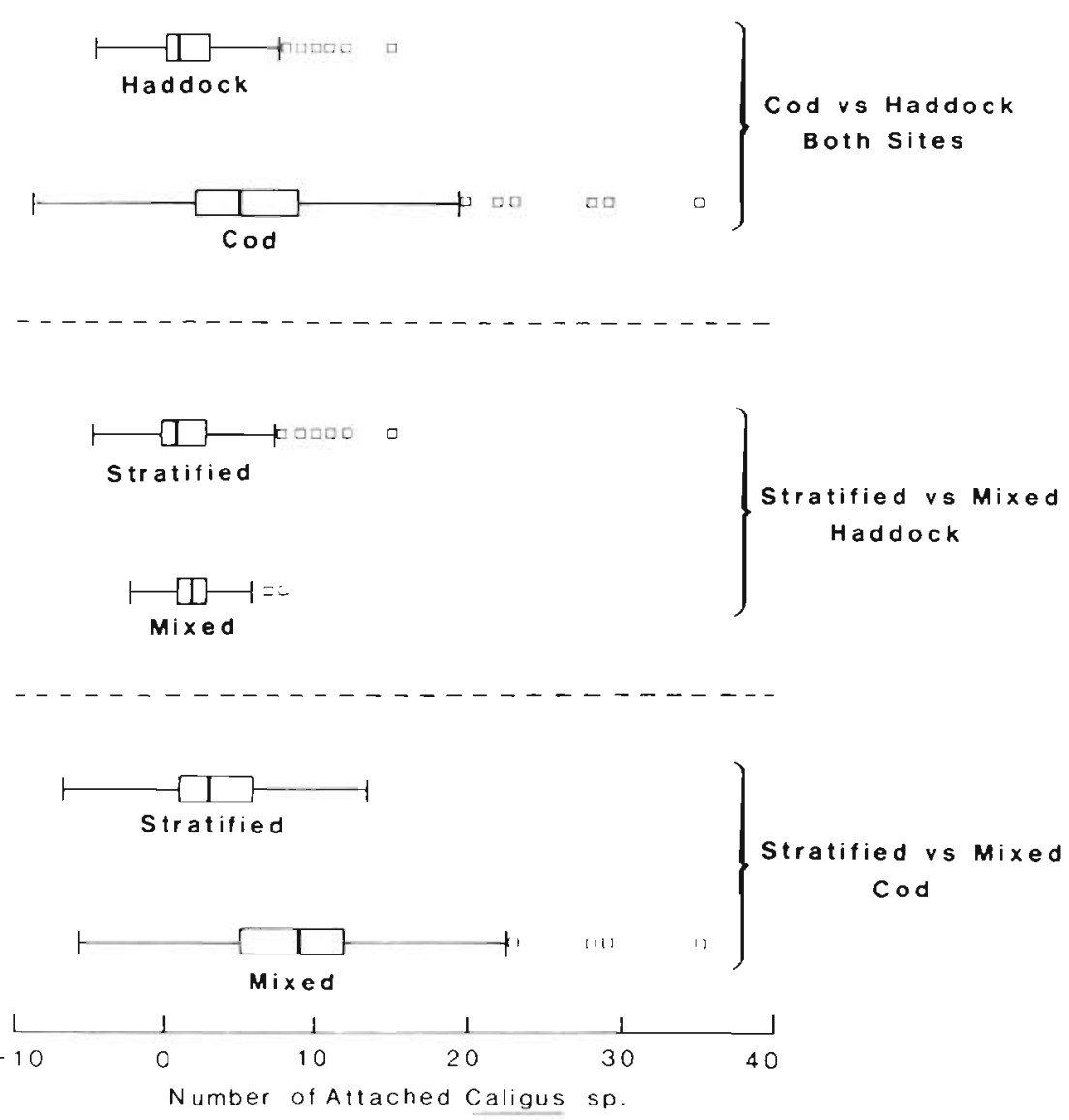

Fig. 9. Box and whisker plots showing comparisons of number of attached Caligus sp. on age-0 gadids. Atlantic cod vs haddock, and haddock and Atlantic cod caught at the stratified vs mixed sites. Georges Bank, 1985

increased drag on swimming ability, reduction of senses such as vision (Brassard et al. 1972) or rendering the host more visible to predators. Such effects would be expected to make fish more prone to predation or capture in nets.

However, we found no evidence of decreased condition in either cod or haddock as a function of parasite biomass. Similarly, there were no significant differences in parasite biomass or numbers in fish caught in different sized nets, although both measures of parasite burden were generally greater in fish caught in smaller gear. The small number of fish involved in the comparison ( $\mathrm{n}=9$ and 47 for the MININESS and IYGPT respectively) may affect the validity of the conclusion that increased parasite burden did not increase the likelihood of capture in the smaller gear.

The extent of parasitism may be a density-dependent phenomenon, such that when fewer fish hosts are available, the number of parasites per host may be increased. In a midwater trawl survey of juvenile gadids conducted on the northeastern portion of Georges Bank in 1986, the mean number of attached Caligus sp. on the juvenile fish was 22.4 and 32.3 for cod and haddock, respectively. In contrast, cod and haddock in 1985 had mean numbers of attached Cali- gus sp. of 6.2 and 2.1, respectively. Table 2 indicates the average catch per tow of both cod and haddock was markedly higher, and mean lengths slightly larger, in 1985 compared with 1986. This difference in mean lengths between years is not sufficient, however, to account for the much higher numbers of parasites per fish in 1986 (Fig. 8).

We found a greater proportion of haddock compared with cod in the MININESS sets than would have been expected given the results of the concurrent IYGPT sets (ratios of cod: haddock caught were 0.320 and 4.415 for MININESS and IYGPT respectively). The greater number of Caligus sp. ectoparasites attached in the vicinity of the eye of haddock compared with cod (Fig. 6) may be responsible for this observation. The field of vision of fish is virtually $360^{\circ}$ but with a posterior blind spot caused by the shadow of the fish's body (Muntz 1971). The occlusion of fishes' vision could be increased considerably by the occurrence of Caligus sp. ectoparasites around the eye, which would then screen the approach of a predator, or fishing gear.

The hypothesis that Caligus $\mathrm{sp}$. ectoparasitism is a source of natural mortality might account for the decreasing parasite burden as a function of fish length (Fig. 8), with heavily parasitized fish being removed 
Table 1. Gadus morhua and Melanogrammus aeglefinus. Stomach contents of Georges Bank age-0 cod and haddock. ranked in descending order by number of occurrences. Only those prey items that occurred in $>1 \%$ of guts examined are included. Number of stomachs examined was 235 and 130 for cod and haddock, respectively, at the stratified site, and 178 and 180 , respectively, at the mixed site. Caligus sp. is highlighted (bold-face type) amongst the rankings

\begin{tabular}{|c|c|c|c|c|}
\hline $\begin{array}{l}\text { Fish } \\
\text { species }\end{array}$ & Pre: item & Stage & $\begin{array}{l}\% \text { of stomachs } \\
\text { with prey item }\end{array}$ & $\begin{array}{c}\text { No, of occurrences } \\
\text { of prey item }\end{array}$ \\
\hline \multicolumn{5}{|c|}{ STRATIFIED SITE } \\
\hline \multirow[t]{15}{*}{ Cod } & $\overline{C a l i g u s}$ elongatus & Egg & 4.8 & 396 \\
\hline & Tisbe sp. & Adult & 7.0 & 315 \\
\hline & Calanoida & Adult & 9.6 & 229 \\
\hline & Pseudocalanus minutus & Adult & 8.7 & 105 \\
\hline & Invertebrate eggs & Egg & 3.5 & 75 \\
\hline & Caligus sp. & Adult & 13.1 & 61 \\
\hline & Pagurus sp. & Megalopa & 10.0 & 30 \\
\hline & Sagitta elegans & Adult & 5.7 & 15 \\
\hline & Crustacea & Adult & 1.3 & 12 \\
\hline & Limanciasp. & Adult & 2.2 & 11 \\
\hline & Hyperia sp. & Adult & 3.1 & 10 \\
\hline & Calanus finmarchicus & Adult & 3.1 & 10 \\
\hline & Gammaridae & Adult & 1.7 & 6 \\
\hline & Hyperia sp. & Subadult & 1.3 & 6 \\
\hline & Chaetognatha & Adult & 1.7 & 4 \\
\hline \multirow[t]{27}{*}{ Haddock } & Invertebrate eggs & Egg & 8.5 & 1890 \\
\hline & Limancia sp. & Adult & 41.5 & 114 \\
\hline & Hyas coarctatus & Megalopa & 24.6 & 74 \\
\hline & Hyperia sp. & Juvenile & 3.8 & 72 \\
\hline & Pandalidae & Adult & 18.5 & 66 \\
\hline & Caligus sp. & $\mathrm{Egg}$ & 0.8 & 60 \\
\hline & Pagurus acadianus & Megalopa & 11.5 & 46 \\
\hline & Pagurus sp. & Megalopa & 11.5 & 37 \\
\hline & Dichelopandalus leptocerus & Juvenile & 6.9 & 20 \\
\hline & Caridea & Mysis & 6.2 & 19 \\
\hline & Gadidae & Juvenile & 10.0 & 17 \\
\hline & Calanoida & Adult & 1.5 & 12 \\
\hline & Hyperia medusarum & Adult & 6.9 & 11 \\
\hline & Caligus sp. & Late chalimus & 0.8 & 10 \\
\hline & Hyperia sp. & Subadult & 1.5 & 6 \\
\hline & Centropages sp. & Adult & 2.3 & 5 \\
\hline & Caridea & Adult & 3.1 & 5 \\
\hline & Crustacea & Adult & 2.3 & 4 \\
\hline & Dichclopandalus leptocerus & Adult & 2.3 & 4 \\
\hline & Thysanoessa sp. & Adult & 2.3 & 4 \\
\hline & Sagitta elegans & Adult & 1.5 & 3 \\
\hline & Melanogrammus aeglefinus & Juvenile & 2.3 & 3 \\
\hline & Bathynectes superba & Zoea & 1.5 & 2 \\
\hline & Pandalidae & Juvenile & 1.5 & 2 \\
\hline & Meganyctiphanes norvegica & Adult & 1.5 & 2 \\
\hline & Neomysis americana & Adult & 1.5 & 2 \\
\hline & Caligus elongatus & Adult & 1.5 & 2 \\
\hline \multicolumn{5}{|c|}{ MIXED SITE } \\
\hline \multirow[t]{15}{*}{ Cod } & Pseudocalanus minutus & Adult & 36.3 & 898 \\
\hline & Crustacea & E:qg & 12.8 & 827 \\
\hline & Centropages sp. & Aduli & 22.3 & 584 \\
\hline & Calanus finmarchicus & Aduit & 26.3 & 505 \\
\hline & Neomysis americana & Postlarva & 28.5 & 391 \\
\hline & Calanoida & Adult & 17.9 & 288 \\
\hline & Sagitta elegans & Adult & 16.8 & 49 \\
\hline & Neomysis americana & Adult & 145 & 47 \\
\hline & Caligus elongatus & Adult & 4.5 & 23 \\
\hline & Pagurus sp. & Zoea & 1.7 & 5 \\
\hline & Pagurus sp. & Megalopa & 2.8 & 5 \\
\hline & Monoculodes edwardsi & Adult & 2.2 & 3 \\
\hline & Gammaridae & Adult & 1.7 & 4 \\
\hline & Aeginina longicornis & Adult & 1.7 & 3 \\
\hline & Pseudoleptocama minor & Adult & 1.7 & 3 \\
\hline
\end{tabular}


Table 1 (continued)

\begin{tabular}{|c|c|c|c|c|}
\hline $\begin{array}{l}\text { Fish } \\
\text { species }\end{array}$ & Prey item & Stage & $\begin{array}{l}\% \text { of stomachs } \\
\text { with prey item }\end{array}$ & $\begin{array}{c}\text { No. of occurrences } \\
\text { of prey item }\end{array}$ \\
\hline Haddock & $\begin{array}{l}\text { Calanoida } \\
\text { Pseudocalanus minutus } \\
\text { Neomysis americana } \\
\text { Centropages sp. } \\
\text { Calanus finmarchicus } \\
\text { Neomysis americana } \\
\text { Neomysis americana } \\
\text { Sagitta elegans } \\
\text { Pagurus sp. } \\
\text { Caridea } \\
\text { Pagurus sp. } \\
\text { Pandalidae } \\
\text { Caridea } \\
\text { Pandalidae } \\
\text { Aeginina longicornis } \\
\text { Pandalidae } \\
\text { Limancia sp. } \\
\text { Aeginina longicornis } \\
\text { Calanoida } \\
\text { Gammaridae } \\
\text { Monoculodes edwardsi } \\
\text { Polychaeta } \\
\text { Brachyura } \\
\text { Gammaridea } \\
\text { Gadidae } \\
\text { Caligus elongatus }\end{array}$ & $\begin{array}{l}\text { Adult } \\
\text { Adult } \\
\text { Postlarva } \\
\text { Adult } \\
\text { Adult } \\
\text { Juvenile } \\
\text { Adult } \\
\text { Adult } \\
\text { Megalopa } \\
\text { Mysis } \\
\text { Zoea } \\
\text { Adult } \\
\text { Adult } \\
\text { Juvenile } \\
\text { Adult } \\
\text { Postlarva } \\
\text { Adult } \\
\text { Juvenile } \\
\text { Unknown } \\
\text { Adult } \\
\text { Juvenile } \\
\text { Unknown } \\
\text { Zoea } \\
\text { Juvenile } \\
\text { Juvenile } \\
\text { Juvenile }\end{array}$ & $\begin{array}{r}29.7 \\
8.1 \\
41.3 \\
5.2 \\
23.3 \\
2.3 \\
12.2 \\
13.4 \\
22.7 \\
11.0 \\
13.4 \\
7.0 \\
6.4 \\
1.7 \\
8.7 \\
5.2 \\
8.7 \\
7.0 \\
1.7 \\
3.5 \\
4.1 \\
1.7 \\
2.9 \\
1.7 \\
2.3 \\
1.2\end{array}$ & $\begin{array}{r}687 \\
663 \\
638 \\
426 \\
315 \\
163 \\
118 \\
95 \\
77 \\
58 \\
57 \\
50 \\
27 \\
23 \\
23 \\
19 \\
18 \\
17 \\
15 \\
10 \\
9 \\
9 \\
6 \\
3 \\
2 \\
1\end{array}$ \\
\hline
\end{tabular}

Table 2. Gadus morhua and Melanogrammus aeglefinus. Catch rates and mean lengths of cod and haddock on Georges Bank in 1985 and 1986

\begin{tabular}{|c|c|c|c|c|}
\hline & \multicolumn{2}{|c|}{1985 (1st 24 h, mixed site) } & \multicolumn{2}{|c|}{1986} \\
\hline & $\operatorname{Cod}$ & Haddock & Cod & Haddock \\
\hline Mean number per tow & 2295 & 528 & 397 & 1 \\
\hline Mean length $(\mathrm{mm})$ & 34.9 & 46.4 & 32.4 & 36.7 \\
\hline
\end{tabular}

from the population at a faster rate. However, other explanations are equally feasible. For example, the cohort of fish may become parasitized relatively early in their pelagic phase and, as the fish grow, parasites may simply complete their life cycle and detach. The length frequency distribution of parasites (Fig. 7) shows several (possibly 4) modes which may correspond to the successive moult stages resulting from an initial infestation event, perhaps extending over several weeks, when infective stages of Caligus sp. cooccur with the cohort of gadids. If this interpretation is correct, the parasite burden would be expected to gradually decrease, as the Caligus sp. mature and detach. Some support for this view was found in a recent (fall, 1986) bottom trawl survey of groundfish on Georges Bank. Although of a different year-class (1986) than the 1985 year-class gadids reported here, the 2 age-0 haddock caught were at a later stage of development and had adopted the demersal habit. Neither of the fish caught had an infestation of Caligus sp. A further aspect of Fig. 7 is the consistency in both occurrence and magnitude of length classes of Caligus sp. among the 3 length-classes of cod, indicating a lack of size-specificity with regard to host selection.

Even when standardized for fish length, cod had a greater average number of Caligus sp. ectoparasites than did haddock (Fig. 9). Conceivably, the life history of pelagic age- 0 cod is such that they co-occur with the infective stages of Caligus sp. to a greater extent than do haddock. The importance of differences in life history was exemplified by Russell (1933) who commented on the occurrence of Caligus rapax in young whiting Gadus merlangus compared with the absence of such parasites in other closely related gadoids. He specu- 
lated that it was the co-occurrence of young caligids and fish with the jellyfish Cyanea sp. which allowed the parasites to locate the hosts. However, evidence for the association of Cyanea sp. and the infective stages of caligids is not available. In our study, where there was also an absence of information on the distribution of infective stages of Caligus sp., we examined the vertical distribution of adult Caligus elongatus with respect to those of cod and haddock at both the thermally mixed and stratified sites (Fig. 10). Cod and C. elongatus co-occurred at the stratified site ${ }_{i}$ however at the mixed site, $C$. elongatus sp. co-occurred more frequently with haddock than with cod. A knowledge of the distribution of the infective stages in the water column is required to fully understand the mechanism by which fish become infected.

The interaction of Caligus sp. and age- 0 gadids was not limited to that of parasite and host. Both eggs of Caligus sp. and adult Caligus elongatus were significant components of the diet of gadids, particularly cod at the stratified site (Table 1). Moreover, using the electivity index suggested by Pearre (1982), cod were shown to preferentially select $C$. elongatus adults only at the stratified site whereas at the mixed site the proportion of $C$. elongatus among all prey selected did
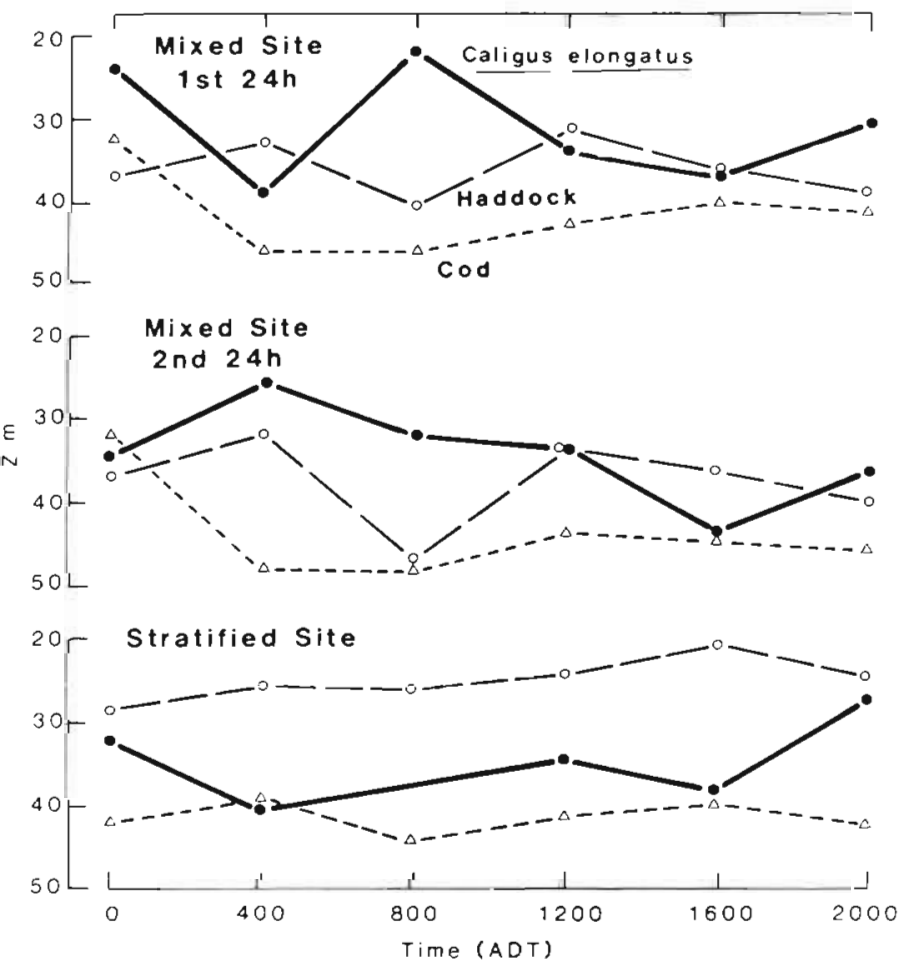

Fig. 10. Caligus elongatus. Plots of the mean depth of the distribution of catch rates vs time, shown with respect to the distributions of age-0 Atlantic cod Gadus morhua and haddock Melanogrammus aeglefinus. $C$ elongatus distributions are drawn with a heavier line to facilitate comparison.

Georges Bank, 1985 not significantly differ from the ratio occurring in the MININESS sets. This probably reflects the availability of prey at both sites, with displacement volumes of zooplankton collected at the mixed site significantly exceeding those sampled at the stratified site (means of 12.30 and $70.29 \mathrm{ml}$ for the stratified and mixed sites respectively, t-test, $\mathrm{p}<0.001$ ). C. elongatus was a less significant component of the diet of haddock, as it was not preferentially selected as a prey item at either site.

Our results are somewhat inconclusive with regard to the effects of Caligus sp. ectoparasitism on juvenile gadids. While we could show no sub-lethal effects in terms of reduced condition, there was circumstantial evidence which indicated that infestations of Caligus sp. may be a source of mortality for age-0 gadids, either directly or indirectly. An indirect source of mortality might include the occlusion of vision in haddock, postulated earlier. Direct mortality might be expected with the removal of the epidermis, dermis and basement membrane resulting from the feeding of the ectoparasite, leading to an inability to osmoregulate. Fish skin provides, as well as some mechanical protection, a barrier of low permeability to water and salts, and damage can be caused by an uncontrolled flow of salts and water across the skin which can often result in osmotic imbalance (Parry 1966). Bacterial or fungal infections associated with such wounds might also be expected to cause difficulty for the fish (Gardner 1974). An example of the severity of the wound and loss of skin associated with the feeding of Caligus $\mathrm{sp}$. on age-0 gadids is shown in a scanning electron micrograph (Fig. 11). Hickey (1979) found that marine fish larvae could tolerate skin removal totalling 1 to $3 \%$ of the surface area, and showed that tolerance increased with fish size. The rate of wound closure can be quite rapid; a $6.6 \mathrm{~mm}^{2}$ removal of skin in a plaice Pleuronectes platessa larva was almost completely covered by epidermis $10 \mathrm{~h}$ after the wound was inflicted (Hickey 1982). The tolerance to skin removal of the larger gadids studied here is not known. Another example of indirect effects is the study of Rosenthal (1967), who found that in 4 herring larvae infested with C. rapax, the incidence of successful strikes at prey was lower than that of unparasitized fish. Further experiments. probably laboratory-oriented, are required to define how Caligus sp. ectoparasitism affects gadids' survival, swimming ability and predator avoidance.

Acknowledgements. We thank $W$ Hogans, Z. Kabata and $M$ McInerney-Northcott for their critical review of an earlier version of this paper Shelley Bray, Randy Losier and Peter Perley assisted with much of the technical work supporting this paper Thanks are also due to Frank Cunningham for preparing the figures and Jeanine Hurley and Brenda Fawkes for word processing services. Maureen McInerney-Northcott (National Research Council, Halifax) prepared the scanning electron micrograph. 


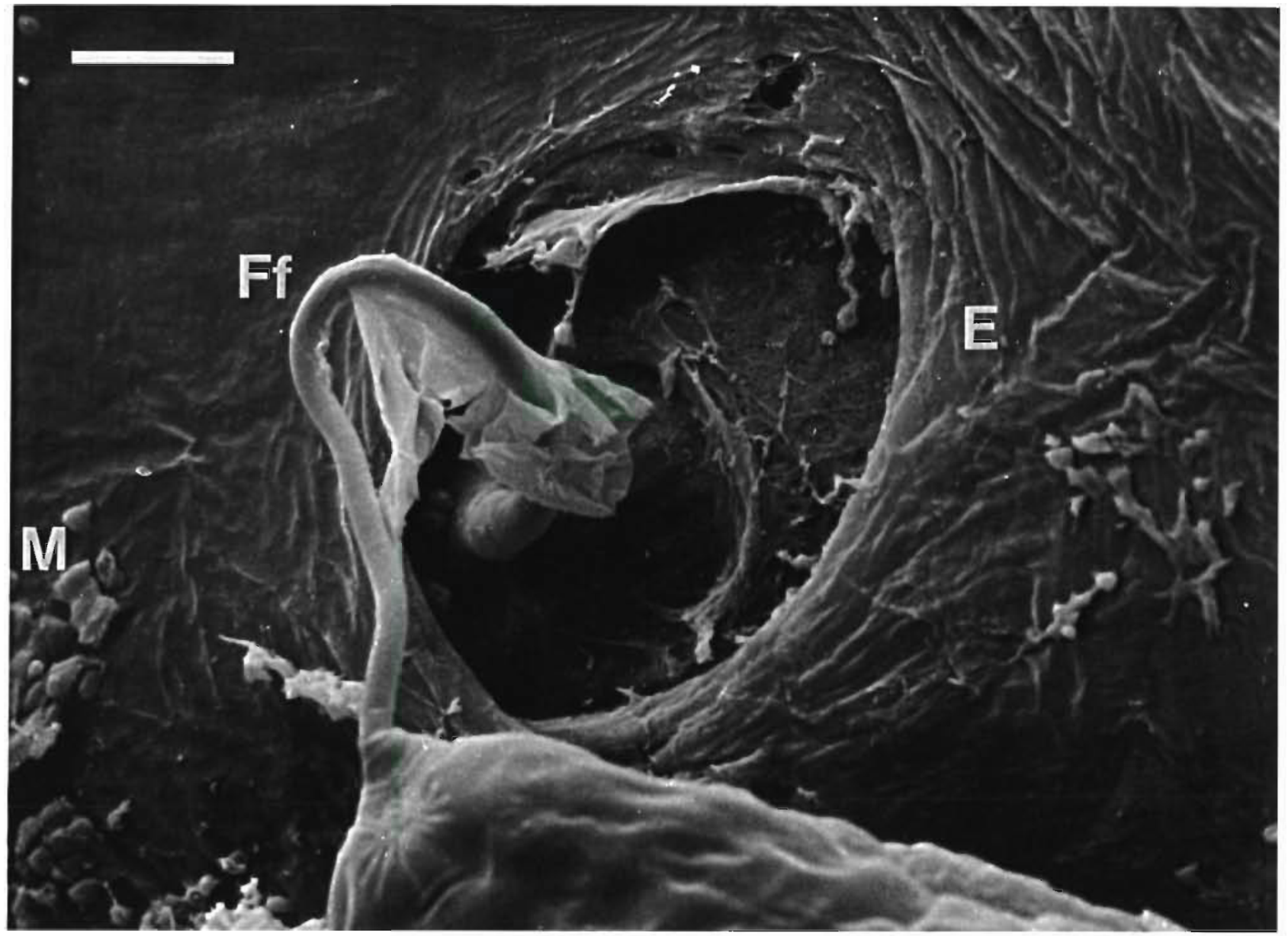

Fig. 11. Melanogrammus aeglefinus. Scanning electron micrograph (260x) showing a wound on an age-0 haddock associated with feeding of the ectoparasite Caligus sp. Ff: frontal filament of the parasite; E: epidermis of the fish; M: mucus residue. Bar = $50 \mu \mathrm{m}$

\section{LITERATURE CITED}

Brassard, P., Rau, M. E., Curtis, M. A. (1972). Parasite-induced susceptibility to predation in diplostomiasis. Parasitology 85: 495-501

Cohen, E. B., Green, J. R., Potter, D. C., Hayden, B. P. (1985) Some preliminary results of juvenile cod and haddock studies on Georges Bank in 1984 and 1985. Coun. Meet. int. Coun. Explor. Sea. C.M-ICES/G: 74, p. 1-23

Dobson, A. P., Hudson, P. J. (1986). Parasites, disease and the structure of ecological communities. Trends Ecol. Evolution 1: 11-15

Gardner, M. L. G. (1974). Impaired osmoregulation in infected salmon, Salmo salar L. J, mar. biol. Ass. U.K. 54: 635-639

Hickey, G. M. (1979). Survival of fish larvae after injury J. exp. mar Biol. Ecol. 37: 1-17

Hickey, G. M. (1982). Wound healing in fish larvae. J. exp. mar. Biol. Ecol. 57: 149-168

Holmes, J. C., Bethel, W. M. (1972). Modification of intermediate host behaviour by parasites. In: Canning, E. U., Wright, C. A. (ed.) Behavioural aspects of parasite transmission. Academic Press, London, p. 123-149

Kabata, Z. (1972). Developmental stages of Caligus clemensi (Copepoda: Caligidae). J. Fish. Res. Bd Can. 29: 1571-1593
Kabata, Z. (1974). Mouth and mode of feeding of Caligidae (Copepoda), parasites of fishes, as determined by light and scanning electron microscopy. J. Fish. Res. Bd Can. 31: $1583-1588$

Kabata, Z. (1981). Copepoda (Crustacea) parasitic on fishes: problems and perspectives. In: Lumsden, W H. R., Muler, R., Baker, J. R. (ed.) Advances in parasitology. Academic Press, London, p. 1-71

Koeller, P. A., Hurley, P. C. F., Perley, P., Neilson, J. D. (1986). Juvenile fish surveys on the Scotian Shelf: implications for year-class size assessments. J. Cons. int. Explor. Mer 43: $59-76$

Muntz, F. W. (1971). Vision: visual pigments. In: Hoar, W. S., Randall, D. J. (ed.) Fish physiology, Vol. V. Sensory systems and electric organs. Academic Press, London, p. 1-32

Parry, G. (1966). Osmotic adaptation in fishes. Biol. Rev. 41: $392-444$

Pearre, S., Jr. (1973). Vertical migration and feeding in Sagitta elegans Verrill. Ecology 54 : 300-314

Pearre, S., Jr. (1982). Estimating prey preference by predators: uses of various indices, and a proposal of another based on $x^{2}$. Can. J. Fish. Aquat Sci. 39: 914-923

Rosenthal, H. (1967). Parasites in larvae of the herring (Clupea harengus L.) fed with wild plankton. Mar. Biol. 1: 10-15 
Russell, F. S. (1933). On the occurrence of young stages of Caligidae on pelagic young fish in the Plymouth area. J. mar. biol. Ass. U.K. 18: 551-553

Sissenwine, M. P. (1984). Why do fish populations vary? In: May, R. M. (ed.) Exploitation of marine communities. Springer-Verlag, New York, p. 59-94
Tukey, J. W. (1977). Exploratory data analysis. Addison-Wesley, Reading, Massachusetts

Wootten, R., Smith, J. W., Needham, E. A. (1982). Aspects of the biology of the parasitic copepods Lepeophtheirus salmonis and Caligus elongatus on farmed salmonids, and their treatment. Proc. R. Soc. Edinb. 81B: 185-197

This article was presented by Dr D. J. Wildish; it was accepted for printing on June 1, 1987 